\title{
Problems of Professional Education of Russian Philology Students
}

\author{
Irina Gladilina ${ }^{1}{ }^{*}$ Valery Volkov ${ }^{1}$, Natalya Volkova ${ }^{2}$ \\ ${ }^{1}$ Department of Russian Language, Tver State University, Russia \\ ${ }^{2}$ Department of Philological Basics of Publishing, Tver State University, Russia \\ *Email: igladilina@yandex.ru
}

\begin{abstract}
The purpose of the work is to construct algorithms for professional reflection and choice of profession of philological profile for students-specialists in Russian Philology. The language material - the names of professions in which students can work is extracted from the texts of business and journalistic speech, the analysis is based on the differentiation of the nuclear and peripheral parts of the field under consideration. The research is carried out at the intersection of pedagogy, linguistic semantics, labor psychology and linguoculturology. It is based on the linguistic technology of constructing semantic fields in combination with linguocognitive analysis. The results showed that the list of "professions for philologists" and their systematization should be based on the following grounds: 1) "universal" philological professions that are in demand in all institutional spheres of society; 2) "specialized" philological professions that are important mainly for the media, education, and culture. The practical value of the obtained results lies in the possibility of using them for professional education of students-specialists in Russian Philology in order to organize professional reflection and achieve a meaningful choice of the field of professional activity.
\end{abstract}

Keywords: Russian studies, Professional self-determination, Professional education, Cognitive linguistics, Lexical and semantic field.

\section{INTRODUCTION}

Russian Philology is a set of sciences about the natural human language and texts in this language, Russian studies is a part of Philology, its objects are the Russian language and further texts in Russian, in which the entire culture of the people is linguistically defined from spiritual peaks to business and personal correspondence. The connection of Russian studies as a science with specific areas of professional activity and specific professions for students-specialists in Russian Philology is not always obvious. This non-obviousness is not without its paradoxical nature: no sphere of Russian life is complete without Russian Philology, but Russian philologists themselves, including students in Russian Philology on the threshold of professional selfdetermination, are not always aware of this.
In the case of a university with a pedagogical profile, the link "Russian studies (science) - a teacher of the Russian language and literature (profession)" is set initially, but in such multi-profile universities that are not specifically profiled for the tasks of training teachers, Russian students find themselves in a situation of extremely wide and complex professional choice due to the breadth. In what fields of activity are their knowledge, skills, and special philological skills in demand? What are the names of those specific professions the officially recognized types of work that can form the basis of a work biography? What are the specific requirements of these professions for employees?

The students in Russian Philology need clear answers to these questions, as well as human resources specialists. However, at the moment, as far as the authors know, there is not even a sufficiently extensive 
(not to mention "complete") list of those professions or at least those areas of professional activity that, on the one hand, need specialists with an academic philological education, and on the other hand, can act as points of application of forces for students, and then graduates of Russian studies.

\section{PROBLEM STATEMENT}

What is the essence of Philology as a scientific specialty and as a broad field of professional activity that is associated with the naming of a person by occupation - philologist? The most concise and succinct explanation: a philologist is a person who is able to read, understand, and, if necessary, correct, and prepare any text for distribution. "Understand" - of course, not to the extent of a specialist, for example, in solid state physics or purulent surgery, but only to the extent of the necessary clarity, accuracy, correctness and other qualities that relate to the concept of "good speech". You need to learn to understand, and therefore analyze, "disassemble" and "collect again" (any) texts on the most complex material. As the great Russian commander A.V. Suvorov said, " it is hard to learn easy in battle." The most complex of human writings (except for inspired texts such as the Bible or the Koran) are works of high literary classics. Such as the British people have Shakespeare, the French people have Rabelais, the Russian people have Pushkin and Leo Tolstoy. Therefore, the focus of Philology departments is on two types of subjects: one related to language, the other - to the classics of fiction. The academic training is based on them. All other academic subjects, such as Philosophy, Economics, and others, are a useful tool. Russian Philology students mostly come to the university in order to "learn more" about Russian literature and the Russian language, have extremely poor ideas about their professional self-realization after graduation, or even do not think at all about the possible specific areas of application of the knowledge and skills they receive at the university to work with texts. The purpose of the article is to develop algorithms for professional reflection and choice of philological profession for Russian Philology students; the achievement of this goal is based on the establishment of a list of "professions for philologists" and the construction of their pedagogically oriented systematization.

\section{METHODOLOGY}

The object of research is the names of professions that together form the lexical and semantic field "Professions for philologists". Language material, which contains the names of professions in which Russian Philology students can work, is extracted by the authors from scientific (including popular science [1]) and business texts, as well as from data on employment, on those areas of professional activity of Philology students that are directly or indirectly related to their higher philological education. Based on the analysis of the material already used by the authors of the method [2], it was placed the distinction between nuclear and peripheral parts of the field, the main research method cognitive reconstruction of the field through the establishment denotative-referential - "real life" relations of concepts "language" and "profession" (the sphere of professional activities).

\section{RESULTS AND DISCUSSION}

\section{1. "Algorithm" of professional reflection of a Russian Philology student}

The effectiveness of professional education of Russian Philology students depends on how much information about the various professions and areas of professional activity in which philological competencies are in demand, students reflexively correlate with their own capabilities and intentions, with their system of values and plans for personal and professional selfrealization. This is the task of professional reflection, the goal is professional identification.

Professional education, which is not closely linked to professional reflection, is focused only on professional knowledge. Such knowledge is absolutely necessary, for example, for a human resources specialist (HR manager), who, after additional training, can and often does act as a philologist. However, for the majority of Russian Philology students, what is needed is not knowledge about the basics of professionography, but specific skills of orientation in the world of professions. These skills are the basis of the students' personal professional marketing as a form of marketing identity (synonymous terms: marketing yourself, or selfmarketing, self-marketing, automarketing, egomarketing, etc.), the foundation of which are, as shown by A. Norida, N.M. Tajudin et al., honest selfassessment and forecast their own performance - selfefficacy [3], that further, on the advice of P.H. Brisk can give the result in the preparation of a resume and preparation for interview with the employer [4].

The student's professional reflection is based on two basic intentions: 1) not devoid of romance "search for a vocation"; 2) pragmatically oriented "search for a suitable job". The starting point of reflection is to find the optimal combination of these intentions, the desired result is the acquisition of professional identity as a successful combination of professional activity and selfrealization, when "identity" and "personality", "self" "identity" are interrelated [5]. Pedagogical support of professional reflection in this approach is reduced to the task of synthesizing professional and life selfdetermination of students [6], which can be achieved 
only if individually differentiated psychological and pedagogical support is provided [7].

Based on our material, we develop the provisions set forth by D. Beijaard, P.C. Meijer, E.G. Belyakova, I.G. Zakharova, S.L. Lesnikova, and others, and formulate key tasks that represent the dynamics of professional reflection: 1) the assessment of their own achievements and the opportunities that are in the zone of proximal (professional) development; 2) the analysis of the specificity of different sectors of society and related to specific occupations; 3 ) the assessment of their personal opportunities and forecasting potential professional career [8] in various fields of employment and in specific occupations; 4) the evaluation of the results of reflection on ethical grounds [9], the correlation of terms of the potential of a professional career with personal moral principles.

In this paper, we focus on the third point - the choice of a profession and the field of work. Since personal marketing in a situation of professional selfdetermination is based on the search for naming an individually acceptable specific profession / professions, the more accurate naming of this type of professional reflection is professional marketing or personal professional marketing, its ultimate goal is to construct an individual-personal list of potentially acceptable professions and/or fields of activity related to Philology.

The search components for an individually acceptable list of professions found by the authors for Russian Philology students: 1) the institutional sphere of society, formally displayed, for example, in the names of ministries and departments; 2) science or scientific discipline related to this field, and related areas of training in the higher education system; 3) specific professions and/or activities necessary for the functioning of this sphere of society.

\subsection{Universal philological professions}

The authors of this work call "universal " such philological professions, which form the core part of the field under consideration, due to the fact that they are in demand in all institutional spheres of society. The reason for the wide demand and at the same time the essence of "professions for philologists" is obvious from their specific place in the scientific systematics of professions. According to the specifics of the subject, goals, means and working conditions, these are professions of the "person-to-person" type [10]. Since Philology is appropriate to understand as the theory and practice of any interaction between people in the natural ("maternal") language, all types of professional activities that include a variety of communication interactions as a mandatory component, for example: business (including regulatory, managerial), pedagogical, ideological (including political), religious, aesthetic and other, that is, interactions in the field of science and production, education and culture, health, trade, etc.

A good example of a "universal" philological profession is a copywriter. Strictly speaking, this is not a profession, but a type of activity that boils down to creating meaningful, well-structured texts in logical and stylistic terms. Copywriting is the basis of any organization's information interaction with the environment, which is why it is a necessary component of "public relations", marketing and advertising. Hence there is the algorithm for selecting a universal profession in Figure $1\left(\mathrm{P}_{i}-\right.$ any "universal" profession, $\mathrm{W}-$ possible areas of work).

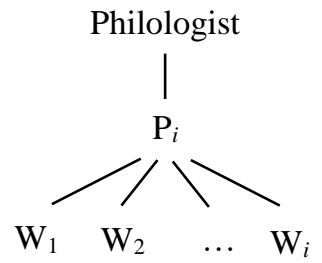

Figure 1 Algorithm for choosing a philologist's place of work: from the features of a "universal" profession to the choice of an acceptable field of activity.

The list of institutional spheres of society is not strictly defined, it is clear from the peculiarities of the organizational and managerial structure of the state, the established traditions of economic and cultural life. For modern Russia, it is essential to identify the following key areas that are directly or indirectly related to the professional activities of philologists: politics and public administration, the armed forces (military affairs), economics and finance (industry and agriculture, banking), trade and entertainment (for example, tourism), transport and communications (mass media), religion and the church, education and health, culture and art, sports.

The exchange of information between organizations is the exchange of its material carriers - documents. Hence there is the possibility of combining the tasks of philological professionalization and at the same time labor "deprofessionalization" [11] - the diversification of professional choice. According to our data, Russian Philology students often focus on "universal" professions related to document management and publishing.

Document science is a scientific discipline, theory and practice of compiling and using documents - texts in natural language. Since a philologist is, relatively speaking, a "specialist in texts", the philological component must be included in the concept of "documentation support for management". Specific "professions for philologists" in the field of business document management: generic naming of the 
document specialist, then naming by private, specific duties of the employee: secretary, clerk, referent, archivist, etc., depending on the specifics of the organization.

Publishing is a branch of the economy (preparation, publication, distribution of any printed products), in close connection with it - the scientific discipline of book business (book study); professions "for philologists": reviewer, editor (hereinafter: chief, leading, scientific, literary editor), proofreader, layout designer (technical editor).

\subsection{Specialized philological professions}

If the core of the field "Professions for philologists" is the names of "universal" professions, then its periphery is the names of professions specific to individual institutional areas. The algorithm for choosing a specialized profession is the reverse of choosing a "universal" profession: as shown in Figure 2, it is built from the initial choice of the field of activity to the forecast of opportunities for professional selfrealization.

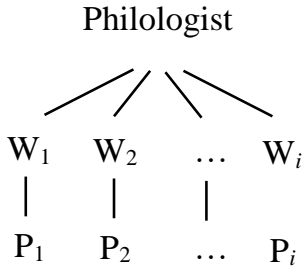

Figure 2 Algorithm for choosing a specialized profession: from an acceptable field of activity to the choice of a specific profession.

To successfully implement the above algorithm of professional reflection, a student needs a thorough knowledge of the structure and functioning of society, as well as a set of different competencies related to information processing (according to M. Salman, Sh.A. Ganie, I. Saleem [12], up to 16 types of competencies can be used). The following is the data obtained by the authors on the names of those specific professions that are of interest to Russian Philology students of the Russian Federation.

Education is the most obvious sphere of professional self-realization of Russian Philology students. Scientific disciplines - pedagogy, psychology, methods of teaching (language, literature), professions - teacher (generic naming), further naming by specific tasks: teacher (in higher education), educator, methodologist, tutor, governess, etc. (according to the specifics of the organization).

Mass media/communications, scientific disciplines journalism, communicology; professions for philologists: generic name journalist, then for specific tasks: reporter, correspondent, columnist, etc., including publishing professions.

Culture. Museum. Scientific discipline - museology (museum business), professions "for philologists": guide (guide-translator), teacher, methodologist, in literary museums - museum curator, researcher, exhibition curator, expositionist. Theatre. Scientific discipline theater studies, professions "for philologists": head of the literary part, prompter. Library. Scientific disciplines - library science, bibliography and book science, professions "for philologists": librarian, bibliographer, caretaker (in reading rooms), database administrator, administrator of technical, musical, historical literature, keeper (book archives, handwritten old books).

The far periphery of the field of "Professions for philologists" is vaguely wide, since the professional training of any philologist is centered on the formation of communicative competencies in those aspects that are related to the terms (1) communication communication or transmission by means of language of the content of utterances, (2) conversation - mutual relations, business or friendly communication. Communicative competence consists of a variety of skills of speech influence and interaction, which are necessary both in everyday life and professionally significant situations of interpersonal and other communication contacts (for example, in business correspondence between institutions and organizations, in business negotiations, in advertising, etc.)

Hence there are the abbreviated versions of the "algorithms" for searching for a profession based on various associative relationships in the "activity profession" parameters, for example: book trade commodity expert, salesman; Internet communication web designer, content manager; recreation and entertainment - holiday organizer, animator; restaurant, café -administrator, bartender; medicine - librarian therapist ("therapy by thoughtful reading of necessary books"); environmental protection - public inspector; image science - image maker, teacher of eloquence; radio, television - presenter, editor, assistant director; business - entrepreneur, clerk, etc. A Russian Philology student will find a worthy place in any socially significant business.

\section{CONCLUSION}

As a result of the study, it was found that Russian Philology students who receive academic philological education find themselves in a situation of vaguely wide professional choice. It is difficult for graduates to cope with the task of choosing for the following reasons: 1) lack of sufficiently extensive ideas about the "professions for philologists" that involve academic 
education; 2) lack of ideas about ways to make a conscious professional choice.

In theoretical terms, based on the generalization of experience with Russian Philology students, the authors of this work state the need to distinguish: 1) "universal" philological professions represented in various spheres of society; 2) specialized philological professions specific to individual institutional spheres.

In practical terms, in the case of "universal" professions, students are encouraged to make professional choices in the following order: a) awareness of the specifics of the profession; b) choosing the sphere of social life (work) in which this profession is in demand, assessing its personal acceptability. In the case of specialized professions, the order is reversed: a) choosing a personally acceptable field of work; b) familiarity with those professions within the chosen field that are based on academic philological training.

\section{AUTHORS' CONTRIBUTION}

I.V. Gladilina - designing and testing algorithms for professional reflection of Russian Philology students.

V.V. Volkov - theoretical development of directions of professional diversification of Russian Philology students.

N.V. Volkova - definition of the lexical and semantic field "Professions for philologists", brief description of professions.

\section{REFERENCES}

[1] E.S. Romanova, 99 popular professions, Psychological analysis and job description, Peter, 2003, 464 p. (In Russ.).

[2] V.V. Volkov, N.V. Volkova, I.V. Gladilina, Russian mentality and European identity, The linguistic aspect of the problem, in: The European Proceedings of Social \& Behavioral Sciences, LVIII, 2019, pp. 2068-2077. DOI: https://dx.doi.org/10.15405/epsbs.2019.03.02.240

[3] A. Norida, N.M. Tajudin, H. Kalthom, Z. Jano, M. Sharif, M. Shahrulanuar, Model of self-esteem, job-search intensity and career decision-making self-efficacy for undergraduate students, in: A. Kasim, W.W. Omar, N.A. Razak, M.N. Wahidah, R.A. Halim, S. Mohamed (Eds.), Proceedings of the International Conference on Science, Technology and Social Sciences (ICSTSS) 2012, Springer, Singapore, 2014, pp. 257-265. DOI: https://doi.org/10.1007/978-981-287-077-3 31

[4] P.H. Brisk, Creating your CV as a self marketing tool, Bookboon, 2011, 118 p.
[5] D. Beijaard, P.C. Meijer, N. Verloop, Reconsidering research on teachers' professional identity, in: Teaching and Teacher Education 20 (2004) 107-128. Retrieved from: https://openaccess.leidenuniv.nl/handle/1887/1119 $\underline{0}$

[6] M.A. Leibovsky, E.L. Fedotova, Pedagogical conditions for successful personality-oriented social and professional self-determination of University students, in: Higher education today 1 (2018) 16-19. Retrieved from: https://www.elibrary.ru/download/elibrary 323717 66 79481332.pdf (In Russ.)

[7] E.G. Belyakova, I.G. Zakharova, Professional selfdetermination and professional identity of studentsteachers in the conditions of individualization of education, in: The Education and Science Journal 22-1 (2020) 84-112. DOI: https://doi.org/10.17853/1994-5639-2020-1-84-112

[8] S.L. Lesnikova, M.G. Leukhova, Professional selfdetermination of university students as the condition of professional identity: the aspect of attitude to the professional career, in: Baltic Humanitarian Journal 7-3(24) (2018) 253-256. Retrieved from: https://www.elibrary.ru/download/elibrary_362379 36 53987557.pdf

[9] S.E. Motornaya, Human formation as a labor subject in the space of higher education: research of spiritual and moral bases of professionalism, Baltic Humanitarian Journal 9-2(31) (2020) 129134. DOI: https://doi.org/10.26140/bgz3-2020$\underline{0902-0033}$

[10] E.A. Klimov, Psychology of professional selfdetermination, Academy, 2010, 304 p. (In Russ.).

[11] Yu.R. Vishnevskiy, D.Yu. Narkhov, Ya.V. Didkovskaya, Trends in higher vocational education: professionalization or deprofessionalization, in: The Education and Science Journal 1(20) (2018) 152-170. DOI: https://doi.org/10.17853/1994-5639-2018-1-9-170

[12] M. Salman, Sh.A. Ganie, I. Saleem, The concept of competence: a thematic review and discussion, in: European Journal of Training and Development, Iss. 44, 2020. DOI: https://doi.org/10.1108/EJTD10-2019-0171 